\title{
Seasonal Progress of Phomopsis longicolla Infection on Soybean Plant Parts and Its Relationship to Seed Quality
}

\author{
Alemu Mengistu, USDA, ARS, Crop Genetics and Production Research Unit, Jackson, TN 38301; Lisa Castlebury, \\ USDA, ARS, Systematic Botany and Mycology Laboratory, Beltsville, MD 20705, Rusty Smith, Jeff Ray, and \\ Nacer Bellaloui, USDA, ARS, Crop Genetics and Production Research Unit, Stoneville, MS 38776
}

\begin{abstract}
Mengistu, A., Castlebury, L., Smith, R., Ray, J., and Bellaloui, N. 2009. Seasonal progress of Phomopsis longicolla infection on soybean plant parts and its relationship to seed quality. Plant Dis. 93:1009-1018.

Phomopsis longicolla is a major seed pathogen of soybean (Glycine max) in hot, humid environments. The objective of this study was to monitor the infection and development of P. longicolla on vegetative and reproductive tissues of six cultivars and to determine the relationship between this infection and subsequent seed infection and seed germination. Cultivars were grown for 3 years (2002 to 2004) without irrigation or with irrigation applied at pre- plus postflowering or at postflowering growth stages. P. longicolla was isolated most frequently from leaf, stem, pod, root, and seed. Diaporthe phaseolorum and three unidentified Phomopsis sp. were also isolated. Diaporthe aspalathi, which previously has not been reported on soybean, was also recovered from leaf samples. These isolates, however, were recovered very infrequently. Recovery of $P$. longicolla from roots was much lower than from leaves, stems, and pods in all years and irrigation environments. The recovery of $P$. longicolla from seed was affected by irrigation environments. Seed from irrigated plots had more $P$. longicolla than that from nonirrigated plots. Isolation of $P$. longicolla from seed was negatively correlated with percentage of seed germination in irrigated environments but not in the nonirrigated environment. Pod infection was correlated with seed infection in all three irrigation environments. Even though infection of leaves and stems increased with increasing moisture availability, such infection did not consistently correlate with seed infection. Seed germination and seed infection were negatively correlated with percent hard seed. This study provided the first demonstration of the seasonal progression of $P$. longicolla on soybean cultivars grown under three irrigation environments.
\end{abstract}

Infection of soybean (Glycine max (L.) Merr.) seed by Phomopsis longicolla is one of several ubiquitous diseases caused by members of the Diaporthe-Phomopsis complex (13). Pod and stem blight is caused by Diaporthe phaseolorum var. sojae (anamorph P. phaseoli), and stem canker is caused by Diaporthe phaseolorum var. caulivora (anamorph $P$. phaseoli) and $D$. phaseolorum var. meridionalis (7). The Diaporthe-Phomopsis complex is worldwide in distribution and causes more losses in soybean than any other single fungal pathogen (7). Although all of the Diaporthe-Phomopsis spp. are seedborne, $P$. longicolla is the principal cause of Phomopsis seed decay of soybean $(5,7,15,16,20)$. Seed infected with this pathogen may be shriveled, elongated, cracked, and appear white and chalky. However, seed may be infected and not

Corresponding author: Alemu Mengistu

E-mail: amengistu@ars.usda.gov

Accepted for publication 12 June 2009.

doi:10.1094/PDIS-93-10-1009

This article is in the public domain and not copyrightable. It may be freely reprinted with customary crediting of the source. The American Phytopathological Society, 2009. show symptoms. Infected seed generally do not germinate (7).

Infection of soybean seed with $P$. longicolla has resulted in significant economic losses $(1,4,17,18)$ for soybean growers in the midsouthern United States due to increased use of the early soybean production system (ESPS) $(9,10)$. The ESPS is a system of planting early-maturing cultivars from late March through April by growers in the mid-South (9). One of the benefits of using early-maturing cultivars in the ESPS is avoidance of late-season drought. The traditional soybean production system in the mid-South of the 1980s typically involved planting in May or later, with the bulk of the acreage planted with MG (maturity group) VI and VII cultivars (9).

Seed quality losses occur because heavy infection of seed by $P$. longicolla directly affects market grade for grain by increasing the number of moldy beans, lowering test weight, and increasing the number of split beans (11), and directly affects the value of seed beans by reducing germination.

Irrigated lands in the Lower Mississippi River Valley have increased at a rate of 77,000 ha per year and surpassed 2.6 million ha in 1997. Arkansas experienced the most rapid increase in irrigation among states in the United States, with more than
1.1 million ha under irrigation during 2006-2007, making it the fourth-ranked irrigated state in the United States (http://www.nass.usda.gov/ar/). Despite annual rainfall greater than $100 \mathrm{~cm}$ in the mid-South, periodic extreme summer droughts make irrigation necessary to avoid crop failure. The expansion of soybean production onto sandy loam and silt loam soils traditionally used as cotton fields in some areas has also created the need for the use of supplemental irrigation. It is essential therefore to provide growers with data on the performance of cultivars under different irrigation environments so that growers are knowledgeable on the level of seed quality they produce at harvest.

Seed infection by $P$. longicolla has been evaluated on soybean produced in rainfed, nonirrigated environments $(2,13,16,19$, 29,31-34,37,38). Overhead irrigation in August and September resulted in an increase in seed infection by Phomopsis sp. (26), but no data were presented on plant infection. Heatherly $(8,9)$ determined that seed quality of early-maturing soybean improved under irrigation compared to nonirrigation, but did not measure the incidence of infection by $P$. longicolla. However, Mengistu and Heatherly (22) found that seeds from furrow-irrigated $\mathrm{MG}$ IV and V soybean had higher levels of infection than seed produced under nonirrigated conditions. Further, infection of seed was significantly higher for MG IV than for MG V cultivars. However, incidence of plant infection was not measured during the growing season. Except for seed quality losses, data on yield effects of Phomopsis seed infection are not available. Use of the fungicide benomyl to control foliar and seedborne diseases has been reported (23). However, its effect in reducing infection on soybean plant parts and seeds was not fully investigated.

Assessment of infection on leaves, stems, roots, and pods, along with its recovery from seed, is needed to better understand the ecology and epidemiology of this pathogen. Therefore, the objectives of this study were to monitor the seasonal progression of infection by $P$. longicolla on soybean treated and untreated with fungicide on leaves, stems, roots, and pods on cultivars from MG II, III, IV, and V grown under three irrigation environments: nonirrigated, pre- plus postflower irriga- 
tion, and postflower irrigation only; and to determine the relationship between plant infection, seed infection, and germination.

\section{MATERIALS AND METHODS}

Field plot design and treatments. Field trials with soybean were conducted in 2002, 2003, and 2004 on a Sharkey clay soil (very-fine, smectitic, thermic chromic
Epiaquert) at the Delta Research and Extension Center, Stoneville, MS $\left(33^{\circ} 26^{\prime} \mathrm{N}\right.$ lat.). Three irrigation environments were established during the season: no irrigation, irrigation applied at pre- plus postflowering, and irrigation applied only at postflowering. Within each irrigation environment, the experimental design was conducted in a split-plot arrangement of

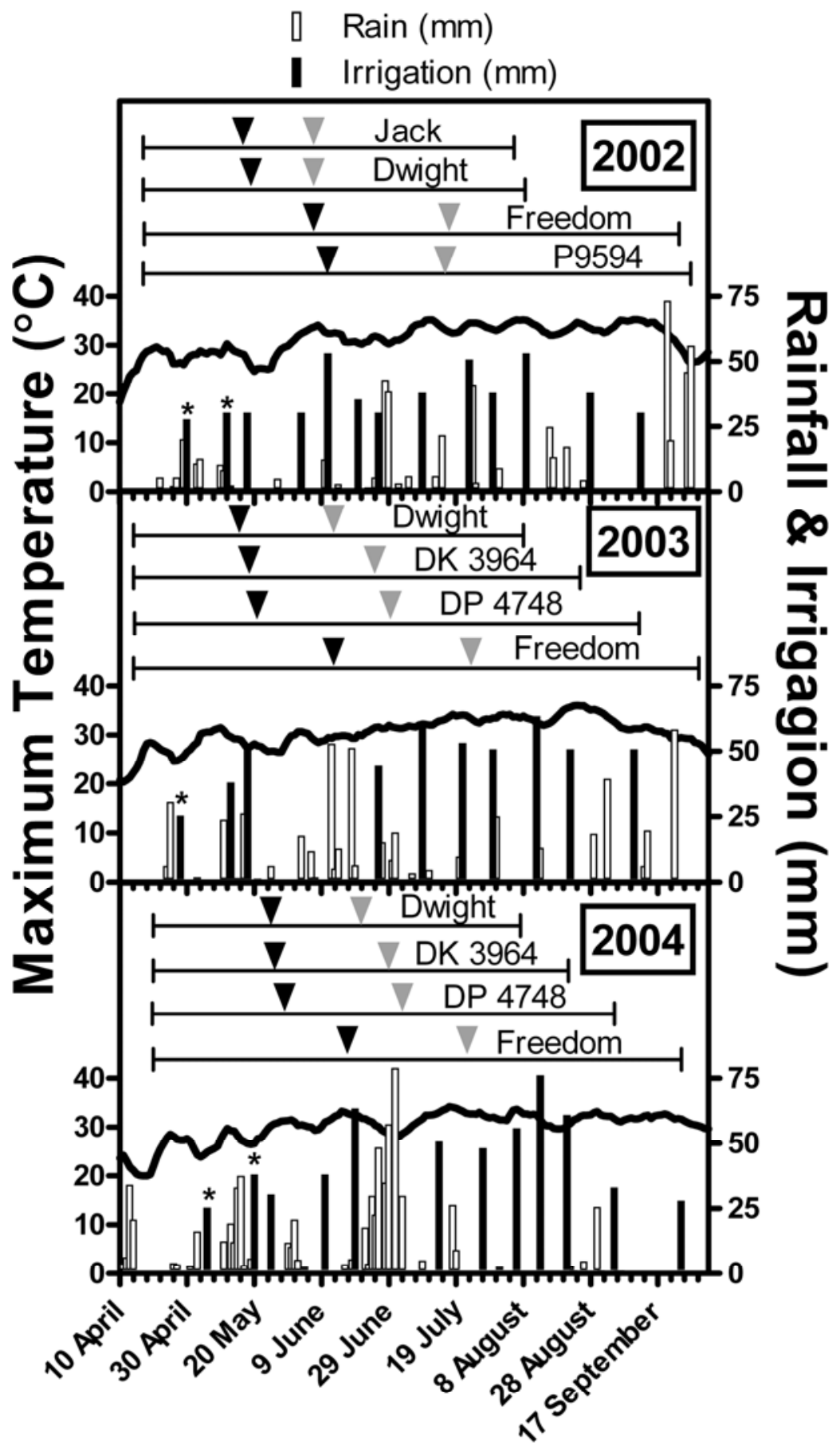

\section{Date}

Fig. 1. Relationships between maximum temperature calculated as a 7-day moving average (thick line near the bottom $1 / 3$ of each panel), rainfall (white bars), and irrigation (black bars) for each year. The time from planting to R8 for each genotype grown each year is represented by the horizontal lines at the top of each panel. The black inverted triangle indicates R1 and the gray inverted triangle represents the R5 stage for each respective genotype. Asterisks indicate irrigation differences between the two irrigated environments.

treatments in a factorial design with cultivars as the main plot and fungicide spray as a subunit treatment. Main unit design was a randomized complete block design with four replications. The same area of land was used each year, and treatments were rerandomized each year. Irrigation of the pre- plus postflower treatment began on 30 April 2002 (15 days after planting [DAP]), 28 April 2003 (14 DAP), and 5 May 2004 (16 DAP). Irrigation of the postflower treatment began on 18 May 2002 (31 DAP), 13 May 2003 (29 DAP), and 24 May 2004 (35 DAP) (Fig. 1). Thus, the designations of irrigation treatments as nonirrigated and pre- plus postflower were appropriate dates for all six cultivars. However, the postflower designation for Pioneer 9594 and Freedom do not approximate the R1 stage. These latematuring cultivars received one to two additional irrigations before they reached reproductive development. For these cultivars, irrigation effect may have been confounded with maturity, and the results need to be viewed in this context.

Six different cultivars were used in this test (Table 1). Initial testing of seeds prior to planting indicated an infection level of less than $1 \%$ for P. longicolla for all seed lots. In addition, seeds were treated with mefenoxam (Apron XL, Syngenta Crop Protection, Greensboro, NC) at $325 \mathrm{ml}$ per $100 \mathrm{~kg}$ of seed prior to planting as a precaution against stand loss due to dampingoff organisms, particularly Pythium sp. All production inputs within a year were identical for all treatments and irrigation environments. Plots were $4 \mathrm{~m}$ (eight rows) wide, with $50-\mathrm{cm}$ spacing between rows, and $23 \mathrm{~m}$ long. Seeding rate was 16 to 20 seed per meter of row. Fungicide was applied once to each cultivar when it reached the R3 growth stage at the rate of $1.12 \mathrm{~kg}$ $\mathrm{ha}^{-1}$. Benomyl fungicide at $50 \%$ a.i. (Benlate, DuPont, Wilmington, DE) was applied to plots with a $\mathrm{CO}_{2}$-pressurized backpack sprayer and hand-held boom with six twin-jet nozzles spaced $0.51 \mathrm{~m}$ apart calibrated to deliver 30 gallons $^{-1}$ at $1.14 \mathrm{~kg}$ per $\mathrm{cm}^{2}$.

Irrigation was applied to designated plots by the furrow method using gated pipe according to Heatherly (9) when soil water potential at the $30-\mathrm{cm}$ depth decreased to approximately $-50 \mathrm{kPa}$ based on tensiometer readings (8). The soil water potential was also determined using watermark sensors (Spectrum Technology, Inc., East Plainfield, IL) that were attached to a micrologger placed in a representative area of the field for each irrigation environment. The sensors were placed within rows at $15-\mathrm{cm}$ depth, and continuous daily soil water potential was recorded. Temperature sensors were also attached to a micrologger to measure soil temperature at 15-cm depth. Data on rainfall, relative humidity, air temperature, and pan evaporation were obtained from the Stoneville 
weather station (http://msa/ars.usda.gov/ $\mathrm{ms} /$ Stoneville/statmsa/weather.htm). After irrigation began, the range of soil water potential for the pre- plus postapplication treatment was maintained between 0 and $-17 \mathrm{kPa}$ over the growing season till maturity; the water potential for postflower irrigation ranged between -16 and -25 $\mathrm{kPa}$. For nonirrigated, the range of soil water potential was very low, especially during the critical stages of crop development in June through August, and ranged between -76 and $-184 \mathrm{kPa}$ (Table 2).

Seeds were planted in tilled seedbeds $(8,9,11)$ prepared with a disk-harrow and/or a spring-tooth field cultivator following soybean harvest the previous fall. This field had been in continuous soybean the previous 3 years. Glyphosate (Roundup, Monsanto, St. Louis, MO) at $0.85 \mathrm{~kg}$ a.i. $\mathrm{ha}^{-1}$ was applied before planting in March of each year to control weeds. Plots were planted 17 April, 14 April, and 19 April in 2002, 2003, and 2004, respectively (Table 1). Fertilizer and herbicide applications were used based on Mississippi State Extension recommendations (18). Harvesting of early-maturing cultivars occurred between irrigation schedules when the soil was just dry enough to allow harvesting equipment to move through the plots.

A field combine modified for small plots was used to harvest the four center rows of each plot at maturity. Harvested seed were adjusted to $12 \%$ moisture content and weighed to determine yield and 100 seed weight.

Inoculum of $P$. longicolla was introduced into the field beginning in late October of each year by manually gathering Phomopsis/Diaporthe infected stems left from previous soybean harvests. These stems were broken into pieces of 2.5 to 7.5 $\mathrm{cm}$ long and were uniformly spread onto the experimental plots on the same day the sample was collected. Also, an isolate from Mississippi (21) was grown on acidified potato dextrose agar (APDA) and was induced to sporulate under a fluorescent light output of $300 \mu \mathrm{mol} \cdot \mathrm{m}^{-2} \cdot \mathrm{s}^{-1}$ with a temperature maintained at $24 \pm 3^{\circ} \mathrm{C}$. Sporulation occurred in about 3 to 4 weeks. Spores at a concentration of $1 \times 10^{6}$ $\mathrm{ml}^{-1}$ were used to spray over the center four rows of each plot when individual cultivars reached R1 (6). The inoculum was applied once on each cultivar with a tractor-mounted sprayer. Inoculation was performed in the evening in order to use dew to aid infection. Even though inoculation was at the R1 stage, the first two samples for isolation (described below) were taken prior to inoculation of the four rows.

Isolation of $P$. longicolla from leaves, stems, roots, and pods. Samples were collected from all cultivars at growth stages V1, V4, R2, R4, R5, R6, and R7 (6). Ten plants were arbitrarily selected from the center four rows of each plot at each sampling date. One leaflet from each plant was removed from the uppermost node with completely unfolded leaves, and a 5mm-diameter leaf disk was collected from the leaflet. A 2-mm-long stem section below the cotyledon node, a 2-mm-long section of the taproot just below the soil line, and a single pod from the fourth uppermost node at the R4 growth stage of each plant were also collected. The samples were wrapped separately in cheesecloth and immersed in $0.25 \% \mathrm{NaOCl}$ for $60 \mathrm{~s}$, blotted, plated separately on APDA (Difco Laboratories, Detroit, MI), and incubated for 5 days at $24^{\circ} \mathrm{C}$. Percent isolation was

Table 1. Soybean cultivars, planting date, the date each cultivar reached reproductive stages, and harvest under nonirrigated, postflower and pre- plus postflower irrigation environments for experiment conducted in 2002 to 2004 at Stoneville, MS

\begin{tabular}{|c|c|c|c|c|c|c|c|c|c|c|c|}
\hline \multirow[b]{2}{*}{ Year } & \multirow{2}{*}{$\begin{array}{c}\text { Date of } \\
\text { planting }\end{array}$} & \multirow[b]{2}{*}{ Cultivars $^{b}$} & \multirow{2}{*}{$\begin{array}{c}\text { Maturity } \\
\text { group } \\
\text { (MG) }\end{array}$} & \multirow[b]{2}{*}{ Growth habit } & \multicolumn{4}{|c|}{$\begin{array}{l}\text { Reproductive stages and corresponding } \\
\text { days after planting }\end{array}$} & \multicolumn{3}{|c|}{$\begin{array}{c}\text { Irrigation environments }{ }^{\mathrm{a}} \text { and } \\
\text { days to harvest }\end{array}$} \\
\hline & & & & & R1 & R5 & R6 & R8 & NI & PF & PPF \\
\hline \multirow[t]{4}{*}{2002} & April 17 & Jack & II & Indeterminate & 31 & 52 & 83 & 111 & 114 & 114 & 114 \\
\hline & & Dwight & II & Indeterminate & 33 & 52 & 85 & 113 & 114 & 114 & 114 \\
\hline & & Pioneer 9594 & V & Determinate & 52 & 92 & 132 & 132 & 155 & 169 & 169 \\
\hline & & Freedom & V & Determinate & 56 & 91 & 132 & 156 & 160 & 169 & 169 \\
\hline \multirow[t]{4}{*}{2003} & April 14 & Dwight & II & Indeterminate & 33 & 61 & 87 & 110 & 115 & 120 & 120 \\
\hline & & DK 3964 & III & Indeterminate & 36 & 73 & 103 & 129 & 134 & 141 & 141 \\
\hline & & DP 4748 & IV & Indeterminate & 38 & 78 & 106 & 149 & 169 & 156 & 156 \\
\hline & & Freedom & $\mathrm{V}$ & Determinate & 61 & 102 & 136 & 169 & 171 & 171 & 171 \\
\hline \multirow[t]{4}{*}{2004} & April 19 & Dwight & II & Indeterminate & 36 & 63 & 89 & 110 & 116 & 116 & 116 \\
\hline & & DK 3964 & III & Indeterminate & 37 & 71 & 102 & 122 & 124 & 130 & 130 \\
\hline & & DP 4748 & IV & Indeterminate & 40 & 75 & 106 & 135 & 138 & 142 & 142 \\
\hline & & Freedom & V & Determinate & 59 & 94 & 127 & 158 & 163 & 163 & 163 \\
\hline
\end{tabular}

${ }^{a}$ Irrigation environments: $\mathrm{NI}=$ nonirrigated, $\mathrm{PF}=$ postflower irrigation, $\mathrm{PPF}=$ pre- plus postflower.

b Jack (MG II), Dwight (MG II), Pioneer 9594 (MG V), and Freedom (MG V) were grown in 2002; Dwight (MG II), DK 3964 (MG III), DP 4748 (MG IV), and Freedom (MG V) were grown in 2003 and 2004.

Table 2. Mean soil water potential for nonirrigated, pre- plus postflower, and postflower irrigation environments, and mean air and soil temperatures, relative humidity, precipitation, and pan evaporation for 2002 to 2004 and 30-year mean for Stoneville, MS

\begin{tabular}{|c|c|c|c|c|c|c|c|c|c|}
\hline \multirow[b]{2}{*}{ Year } & \multirow[b]{2}{*}{ Months } & \multicolumn{3}{|c|}{ Soil water potential $(\mathbf{k P a})^{\mathrm{a}}$} & \multirow{2}{*}{$\begin{array}{l}\text { Air temp. } \\
\quad\left({ }^{\circ} \mathrm{C}\right)\end{array}$} & \multirow{2}{*}{$\begin{array}{l}\text { Soil temp. }{ }^{\text {b }} \\
\quad\left({ }^{\circ} \mathbf{C}\right)\end{array}$} & \multirow{2}{*}{$\begin{array}{l}\text { RH } \\
(\%)\end{array}$} & \multirow{2}{*}{$\begin{array}{l}\text { Precipitation } \\
\text { (total } \mathbf{~ m m} \text { ) }\end{array}$} & \multirow{2}{*}{$\begin{array}{l}\text { Pan evap. } \\
\text { (total } \mathbf{m m} \text { ) }\end{array}$} \\
\hline & & NI & $\mathbf{P F}$ & PPF & & & & & \\
\hline 2002 & $\begin{array}{l}\text { April - Septemberc } \\
\text { June - August }^{\mathrm{d}}\end{array}$ & $\begin{array}{r}-119 \\
-96\end{array}$ & $\begin{array}{l}-21 \\
-25\end{array}$ & $\begin{array}{l}-14 \\
-17\end{array}$ & $\begin{array}{l}33 \\
33\end{array}$ & $\begin{array}{l}35 \\
39\end{array}$ & $\begin{array}{r}99 \\
100\end{array}$ & $\begin{array}{l}610 \\
259\end{array}$ & $\begin{array}{r}1,122 \\
588\end{array}$ \\
\hline 2003 & $\begin{array}{l}\text { April - September } \\
\text { June - August }\end{array}$ & $\begin{array}{l}-119 \\
-136\end{array}$ & $\begin{array}{l}-21 \\
-17\end{array}$ & $\begin{array}{r}-14 \\
-5\end{array}$ & $\begin{array}{l}31 \\
31\end{array}$ & $\begin{array}{l}35 \\
37\end{array}$ & $\begin{array}{l}91 \\
93\end{array}$ & $\begin{array}{l}573 \\
287\end{array}$ & $\begin{array}{r}1,099 \\
559\end{array}$ \\
\hline 2004 & $\begin{array}{l}\text { April - September } \\
\text { June - August }\end{array}$ & $\begin{array}{r}-184 \\
-76\end{array}$ & $\begin{array}{l}-16 \\
-27\end{array}$ & $\begin{array}{l}0 \\
0\end{array}$ & $\begin{array}{l}31 \\
32\end{array}$ & $\begin{array}{l}34 \\
37\end{array}$ & $\begin{array}{l}91 \\
92\end{array}$ & $\begin{array}{l}739 \\
449\end{array}$ & $\begin{array}{r}1,089 \\
542\end{array}$ \\
\hline $\begin{array}{r}30 \text { Years } \\
\text { average }\end{array}$ & $\begin{array}{l}\text { June - September } \\
\text { June - August }\end{array}$ & - & - & - & $\begin{array}{l}32 \\
32\end{array}$ & $\begin{array}{l}33 \\
38\end{array}$ & $\begin{array}{l}91 \\
94\end{array}$ & $\begin{array}{l}449 \\
270\end{array}$ & $\begin{array}{l}960 \\
485\end{array}$ \\
\hline
\end{tabular}

\footnotetext{
${ }^{a}$ Negative soil water potential $(\mathrm{kPa})$ and irrigation environments: $\mathrm{NI}=$ nonirrigated, $\mathrm{PPF}=$ pre- plus postflower; $\mathrm{PF}=$ postflower irrigation .

${ }^{\mathrm{b}}$ Soil temperature taken at 5.1-cm depth.

${ }^{c}$ April - September refers to periods from planting to harvest.

d June - August refers to the critical dry months.
} 
determined by the number of 10 plant samples (leaves, stems, roots, and pods) per plot from which $P$. longicolla was recovered. The area under the isolation curve (AUC) for leaf, stem, and pod samples was calculated based on percent isolation at the seven sampling dates $(35,36)$.

Isolation of $P$. longicolla from seed. Seed samples were taken from the four inoculated rows of each plot at harvest and dried under forced air at $32^{\circ} \mathrm{C}$ for $6 \mathrm{~h}$ so that seeds were of uniform moisture (12\%). Two 100-seed samples were then subsampled from each plot. The first 100 seeds were used to determine incidence of seedborne plant-pathogenic fungi, particularly $P$. longicolla. Seeds were then disinfested in $0.25 \% \mathrm{NaOCl}$ for $60 \mathrm{~s}$, blotted, placed on APDA, and incubated for 5 days at $24^{\circ} \mathrm{C}$ to determine percent isolation of $P$. longicolla. The second 100 seeds were used to determine germination and hard seed. Standard germination tests were conducted in rolled brown paper towels on crepe cellulose paper (Kimpak, Indiana Shipping Supply, Indianapolis), tested at $25^{\circ} \mathrm{C}$ for 7 days $(8,22)$. Hard seed was characterized as seed that did not swell or imbibe water because of an impermeable seed coat during the standard germination test.

Identification of $P$. longicolla and other Phomopsis/Diaporthe spp. Phomopsis spp. growing from samples were subcultured and identified to the species level based morphological and cultural characteristics of single monoconidial isolates $(3,12)$. Each isolate was examined for sporulation, dimensions of conidia, pattern of stroma, and presence or absence of beta conidia and perithecia (7). A total of 30 representative isolates were selected based on morphological and cultural characteristics and sent to the USDA, ARS Systematic Botany and Mycology Laboratory, Beltsville, MD for identification and confirmation. The Phomopsis/Diaporthe isolates were identified using DNA sequencing of an intron containing a portion of the translation elongation factor gene $(21,28)$. DNA sequences from each isolate were compared with reference sequences from the type strain of $P$. longicolla (ATCC $64802=$ FAU 600) and from a well-characterized strain of Diaporthe phaseolorum (Cooke \& Ellis) Sacc. (ATCC $64802=$ FAU 458).

Data analysis. Data were combined over years for each irrigation environment, and analysis of variance (ANOVA) was performed using SAS's general linear mixed model procedure (27) and the least significance difference test at $P \leq 0.05$. Since irrigation environments were not replicated, data from each irrigation environment in all years of this study was analyzed separately. The ANOVA tables are presented to indicate treatment effects within each irrigation environment in all years of this study. The AUC was standardized by dividing AUC by the total length of the disease assessment period in order to make direct comparisons among epidemics with each environment for each cultivar. Correlation analysis was performed on each variable by irrigation to estimate the relationship between disease incidence from leaves, stems, pods, and other parameters to seed infection and germination within each irrigation environment.

\section{RESULTS}

Environmental data. Crop water deficits in the midsouthern United States usually begin to develop in June and continue into September (http://msa/ars.usda.gov/ $\mathrm{ms} /$ Stoneville/statmsa/weather.htm). The relationships among temperature, rainfall, and irrigation from planting to R8 along with the beginning and ending dates for postflower and pre- plus postflower irrigation environments for each year are indicated in Figure 1. The total precipitation from June through August in 2004 was far greater than that of 2002 and 2003 and the 30 -year average (Table 2). Soil in the nonirrigated regime had a lower (more nega-

Table 3. Identification of Diaporthe/Phomopsis isolates, culture deposits (BPI), and GenBank accession for isolates recovered from soybean leaf, stem, root, pod, and seed

\begin{tabular}{|c|c|c|c|c|}
\hline Isolate name & Taxon & $\begin{array}{c}\text { Dried } \\
\text { specimen }^{\mathrm{a}}\end{array}$ & $\begin{array}{c}\text { GenBank } \\
\text { accession no. }\end{array}$ & $\begin{array}{l}\text { Plant part isolated } \\
\text { and growth stage }\end{array}$ \\
\hline STAM57 & P. longicolla & BPI 878896 & FJ785433 & Leaf (V1, V4) \\
\hline STAM62 & P. longicolla & BPI 878899 & FJ785435 & Stem $(\mathrm{V} 1, \mathrm{~V} 6)$ \\
\hline STAM174 & P. longicolla & BPI 878920 & FJ785437 & Root (V1, V3) \\
\hline STAM56 & P. longicolla & BPI 878895 & FJ785438 & Seed \\
\hline STAM64 & P. longicolla & BPI 878900 & FJ785439 & Pod (R2) \\
\hline STAM68 & D. phaseolorum & BPI 878902 & FJ785441 & Stem (R3) \\
\hline STAM128 & D. phaseolorum & BPI 878913 & FJ785443 & Leaf (R3) \\
\hline STAM72 & $\begin{array}{l}\text { Unidentified } \\
\text { Phomopsis sp. }\end{array}$ & BPI 878904 & FJ785431 & Leaf (V6) \\
\hline STAM73 & $\begin{array}{l}\text { Unidentified } \\
\text { Phomopsis sp. }\end{array}$ & BPI 878905 & FJ785440 & Stem (V6) \\
\hline STAM181 & $\begin{array}{l}\text { Unidentified } \\
\text { Phomopsis sp. }\end{array}$ & BPI 878921 & FJ785458 & $\begin{array}{l}\text { Leaf (R1), Stem (R3), } \\
\text { Root (R5), Pod (R5), Seed }\end{array}$ \\
\hline STAM187 & D. aspalathi & BPI 878922 & FJ785432 & Leaf (V3) \\
\hline
\end{tabular}

a *BPI, U.S. National fungus collections, Beltsville, MD. tive) water potential than in the irrigated postflowering or pre- plus postflowering irrigation environment (Table 2). The 2002 June to August air and soil temperatures, relative humidity, and pan evaporation were higher than those of 2003 and 2004.

Identification of $\boldsymbol{P}$. longicolla and other Phomopsis spp. Six Phomopsis/Diaporthe spp. were identified based on morphological characteristics and the internal transcribed spacer (ITS) sequence $(21,29)$ (Table 3). P. longicolla was isolated most frequently (95\%) from leaf, stem, pod, root, and seed. D. phaseolorum $(0.4 \%)$ was isolated from leaf and stem samples, and three unidentified Phomopsis spp. were isolated from leaf samples, stem samples, or all parts including pods and seeds. Diaporthe aspalathi (25), which previously has not been reported from soybean, was also recovered from leaf samples. The three unidentified Phomopsis spp. and $D$. aspalathi, however, were recovered infrequently $(0.1 \%)$. Other fungal species such as Fusarium sp. and Alternaria sp. made up the remaining $4 \%$ of the fungi isolated. Since $P$. longicolla was the most frequently recovered, the data presented in this study are focused solely on this species.

The earliest culturing of $P$. longicolla from leaves, stems, and roots was at the V1 growth stage and from pods at the $\mathrm{R} 4$ growth stage (Table 3). The earliest onset of P. longicolla in Dwight, Jack, Freedom, and Pioneer 9594 was from leaves, stems, and roots in 2003 and 2004, whereas the earliest onset for DK 3964 and DP 4748 was only from leaves and stems in 2003 and 2004. The percent recovery of $P$. longicolla from leaves, stems, and pods was the highest at approximately the R2 stage for Dwight and Jack, while it was approximately at the R5 stage for Freedom and Pioneer 9594 (data not presented). This could be due to a greater number of individual infections or to more extensive or rapid colonization after infection.

AUC based on isolation of $P$. longicolla from leaves, stems, and pods. ANOVA performed on each irrigation environment indicated that isolation from leaf, stem, and pod samples varied significantly among years, and that cultivar effects were dependent on year (Table 4). There was a significant year $\times$ cultivar interaction effect for leaf and stem in all irrigation environments. There was no effect of fungicide on frequency of isolation from leaves or pods. Fungicide and its interaction with year affected isolation of $P$. longicolla from stems under postflowering irrigation in 2003 but not under nonirrigation or pre- plus postflower irrigation environments in any other year. Recovery of $P$. longicolla from roots was very low in all 3 years, and irrigation environments and AUCs are not presented.

When a standardized AUC for cultivars within each irrigation environment 
was compared for 2002, Pioneer 9594 and Freedom (both MG V) had significantly higher AUC for leaf and stem isolations than Jack and Dwight (MG II) across all irrigation environments (Table 5). In contrast, differences in AUC between cultivars in 2003 and 2004 were not the same as in 2002. In 2003 and 2004, Dwight and DK 3964 had a higher, and in most cases significant, AUC than the later maturing cultivars, DP 4748 and Freedom (Table 5).

When comparing year effects for each irrigation environment, the cumulative AUC was significantly lower in 2002 than in 2003 and 2004 for leaf and stem isolations (Fig. 2A and B) in all three irrigations. There was a general increase in AUC for leaf and stem isolations from 2002 through 2004 within each irrigation environment, but no such increase occurred for pod (Fig. 2A and B). However, infection of pods was higher in 2003 than in 2002 and 2004 under each irrigation environment (Fig. 2C). Even though the frequency of isolation from roots remained very low and AUC is not presented, there was also an increase in the frequency of isolation from the roots within each irrigation environment.
Isolation of $P$. longicolla from seeds. ANOVA indicated that there were significant effects due to year, cultivar, and cultivar $\times$ year interaction on seed infection and hard seed, but not for fungicide (Table 6). ANOVA for seed germination indicated an effect due to year and year $\times$ cultivar interaction in the nonirrigated environment. Seed germination depended on cultivar, cultivar $\times$ year, and fungicide interactions under postflower and pre- plus postflower irrigation environments. In addition, there was a significant interaction effect on seed germination due to fungicide $\times$ year interaction under postflower

Table 4. Analysis of variance on the area under the curve for frequency of isolation of Phomopsis longicolla from leaf, stem, and pods of soybean for 2002 through 2004 in Stoneville, MS

\begin{tabular}{|c|c|c|c|c|c|c|c|c|}
\hline \multirow[b]{2}{*}{ Irrigation $^{a}$} & \multirow[b]{2}{*}{ Effect $^{b}$} & \multirow[b]{2}{*}{ df } & \multicolumn{2}{|c|}{ P. longicolla from leaf } & \multicolumn{2}{|c|}{ P. longicolla from stem } & \multicolumn{2}{|c|}{ P. longicolla from pod } \\
\hline & & & $F$ value & $P>F$ & $F$ value & $P>F$ & $F$ value & $P>F$ \\
\hline \multirow[t]{7}{*}{ NI } & Yr & 2 & 53.1 & $<0.0001$ & 80.66 & $<0.0001$ & 9.36 & 0.0006 \\
\hline & Cult & 3 & 4.49 & 0.006 & 2.5 & 0.0662 & 0.16 & 0.9257 \\
\hline & Yr*Cult & 6 & 5.51 & $<0.0001$ & 2.44 & 0.0336 & 0.52 & 0.7928 \\
\hline & Fung & 1 & 1.4 & 0.241 & 1.28 & 0.2616 & 0.66 & 0.4208 \\
\hline & Yr*Fung & 2 & 0.78 & 0.4625 & 0.3 & 0.7386 & 0.22 & 0.8041 \\
\hline & Cult*Fung & 3 & 0.64 & 0.5913 & 0.16 & 0.9233 & 1.81 & 0.1636 \\
\hline & Yr*Fung*Cult & 6 & 0.94 & 0.4705 & 0.39 & 0.8844 & 1.73 & 0.1432 \\
\hline \multirow[t]{7}{*}{$\mathrm{PF}$} & Yr & 2 & 85.48 & $<0.0001$ & 46.85 & $<0.0001$ & 6.35 & 0.0191 \\
\hline & Cult & 3 & 2.26 & 0.0884 & 5.03 & 0.0035 & 0.1 & 0.9609 \\
\hline & Yr*Cult & 6 & 4.67 & 0.0005 & 6.38 & $<0.0001$ & 0.62 & 0.712 \\
\hline & Fung & 1 & 0 & 0.9622 & 5.76 & 0.0194 & 0.67 & 0.4167 \\
\hline & Yr*Fung & 2 & 0.77 & 0.4662 & 5.12 & 0.0087 & 2.35 & 0.104 \\
\hline & Cult*Fung & 3 & 0.82 & 0.4877 & 0.63 & 0.5979 & 0.42 & 0.7423 \\
\hline & Yr*Fung*Cult & 6 & 1.02 & 0.4183 & 1.13 & 0.3562 & 0.46 & 0.8317 \\
\hline \multirow[t]{7}{*}{ PPF } & $\mathrm{Yr}$ & 2 & 73.29 & $<0.0001$ & 62.99 & $<0.0001$ & 5.72 & 0.005 \\
\hline & Cult & 3 & 2.55 & 0.0635 & 5.3 & 0.0039 & 0.15 & 0.9308 \\
\hline & Yr*Cult & 6 & 2.64 & 0.0241 & 11.17 & $<0.0001$ & 0.46 & 0.8345 \\
\hline & Fung & 1 & 0 & 0.9524 & 2.83 & 0.1012 & 0.2 & 0.6564 \\
\hline & Yr*Fung & 2 & 0.76 & 0.4733 & 1.08 & 0.3502 & 0.55 & 0.5771 \\
\hline & Cult*Fung & 3 & 0.14 & 0.9344 & 0.27 & 0.846 & 1.36 & 0.2607 \\
\hline & Yr*Fung*Cult & 6 & 0.32 & 0.9223 & 1.27 & 0.2939 & 0.36 & 0.8997 \\
\hline
\end{tabular}

a Irrigation environments: NI = nonirrigated, $\mathrm{PPF}=$ pre- plus postflower irrigation; $\mathrm{PF}=$ postflower irrigation.

${ }^{\mathrm{b}}$ Abbreviations of fixed effects: $\mathrm{Yr}=$ year, Cult $=$ cultivar, Fung $=$ fungicide.

Table 5. Standardized area under the curve (AUC) $)^{\mathrm{a}}$ of percent isolation of Phomopsis longicolla from leaves, stems, and pods of soybean grown under three irrigation environments ${ }^{\mathrm{b}}$ in 2002, 2003, and 2004 at Stoneville, MS

\begin{tabular}{|c|c|c|c|c|c|c|c|c|c|c|}
\hline \multirow[b]{3}{*}{ Year } & \multirow[b]{3}{*}{ Cultivars ${ }^{\mathrm{c}}$} & \multicolumn{3}{|c|}{ NI } & \multicolumn{3}{|c|}{ PF } & \multicolumn{3}{|c|}{ PPF } \\
\hline & & \multicolumn{3}{|c|}{ P. longicolla isolation from tissues } & \multicolumn{3}{|c|}{ P. longicolla isolation from tissues } & \multicolumn{3}{|c|}{ P. longicolla isolation from tissues } \\
\hline & & Leaves & Stems & Pods & Leaves & Stems & Pods & Leaves & Stems & Pods \\
\hline \multirow[t]{5}{*}{2002} & Jack & 0.32 & 1.04 & 2.84 & 0.14 & 0.77 & 2.79 & 0.45 & 0.95 & 2.75 \\
\hline & Dwight & 0.75 & 0.89 & 2.17 & 0.69 & 0.93 & 2.92 & 0.40 & 0.89 & 3.23 \\
\hline & Pioneer 9594 & 1.92 & 2.86 & 2.31 & 1.74 & 4.02 & 2.58 & 1.65 & 4.34 & 2.67 \\
\hline & Freedom & 2.47 & 2.72 & 2.47 & 2.21 & 3.62 & 2.52 & 1.89 & 4.42 & 2.58 \\
\hline & $\operatorname{LSD}(P \leq 0.05)$ & 0.53 & 0.67 & 0.53 & 0.52 & 0.61 & 0.86 & 0.66 & 0.67 & 0.83 \\
\hline \multirow[t]{5}{*}{2003} & Dwight & 4.32 & 4.53 & 4.82 & 4.18 & 5.12 & 5.41 & 4.36 & 6.23 & 5.27 \\
\hline & DK 3964 & 2.71 & 3.47 & 4.19 & 3.47 & 4.83 & 4.09 & 3.41 & 4.65 & 3.40 \\
\hline & DP 4748 & 2.13 & 3.06 & 3.19 & 2.92 & 3.79 & 3.49 & 3.48 & 3.96 & 3.36 \\
\hline & Freedom & 2.30 & 2.40 & 2.75 & 2.24 & 3.12 & 2.59 & 2.52 & 2.92 & 2.93 \\
\hline & $\operatorname{LSD}(P \leq 0.05)$ & 1.08 & 1.72 & 1.57 & 0.92 & 1.63 & 1.54 & 0.95 & 1.50 & 1.59 \\
\hline \multirow[t]{5}{*}{2004} & Dwight & 5.05 & 8.59 & 3.48 & 5.09 & 7.86 & 3.30 & 4.71 & 7.64 & 3.26 \\
\hline & DK 3964 & 4.02 & 6.23 & 3.07 & 4.98 & 7.07 & 2.93 & 4.75 & 7.13 & 2.89 \\
\hline & DP 4748 & 3.52 & 6.59 & 2.76 & 4.37 & 6.39 & 2.62 & 4.02 & 6.50 & 2.80 \\
\hline & Freedom & 3.48 & 5.60 & 2.42 & 3.63 & 5.63 & 2.25 & 3.64 & 5.15 & 2.30 \\
\hline & $\operatorname{LSD}(P \leq 0.05)$ & 0.78 & 0.86 & 1.05 & 0.89 & 1.18 & 1.14 & 0.89 & 0.97 & 1.08 \\
\hline
\end{tabular}

\footnotetext{
a AUC was calculated based on cumulative recovery of $P$. longicolla.
}

${ }^{\mathrm{b}}$ Irrigation environments: NI = nonirrigated, PF = postflower irrigation, and PPF = pre- plus postflower irrigation. Pioneer and Freedom were still at the late vegetative stage when the PF irrigation was applied at the R1 growth stage. LSD can be used to compare cultivars within each year and irrigation environment. Values represent significance at $P \leq 0.05$.

c Jack (MG II), Dwight (MG II), Pioneer 9594 (MG V), and Freedom (MG V) were grown in 2002; Dwight (MG II), DK 3964 (MG III), DP 4748 (MG IV), and Freedom (MG V) were grown in 2003 and 2004. 
irrigation. Even though fungicide showed an effect, no consistent improvement in seed germination was detected.

Percent isolation of $P$. longicolla from seed did not differ among Dwight (MG II), Pioneer 9594, and Freedom (MG V) under nonirrigation in 2002 but was higher in Jack than in the other cultivars (Table 7). However, in 2002, isolation from Freedom and Pioneer 9594 was significantly greater than that for Jack and Dwight in the two irrigated regimes. In 2003 and 2004, Freedom had the lowest percent isolation from seeds in the postflowering and pre- plus postflowering irrigation environments compared to the other cultivars. In 2003, DP 4748 (MG IV) had significantly higher percentages of isolation of $P$. longicolla than Dwight (MG II), DK 3964 (MG III), and Freedom under all irrigation environments. In 2004, Dwight and DK 3964 had the highest percentages of isolation of $P$. longicolla under postflower and pre- plus postflower irrigation environments, whereas Freedom had the lowest percentages of recovery across all irrigation environments. The percentage of seed infection for Freedom in 2004 was lower than that for the other three cultivars across all irrigation environments, and was also the lowest in nonirrigated in 2002, and in postflowering and pre- plus postflowering irrigation environments in 2003.

Seed germination and $\boldsymbol{P}$. longicolla. In 2002 , percent seed germination was higher in the nonirrigated regime for Pioneer 9594 and Freedom, both MG V, than for Dwight and Jack, both MG II (Table7). In 2003, germination for Freedom was the highest under all irrigation environments, and the corresponding percent isolation of $P$. longicolla was the lowest among culti-
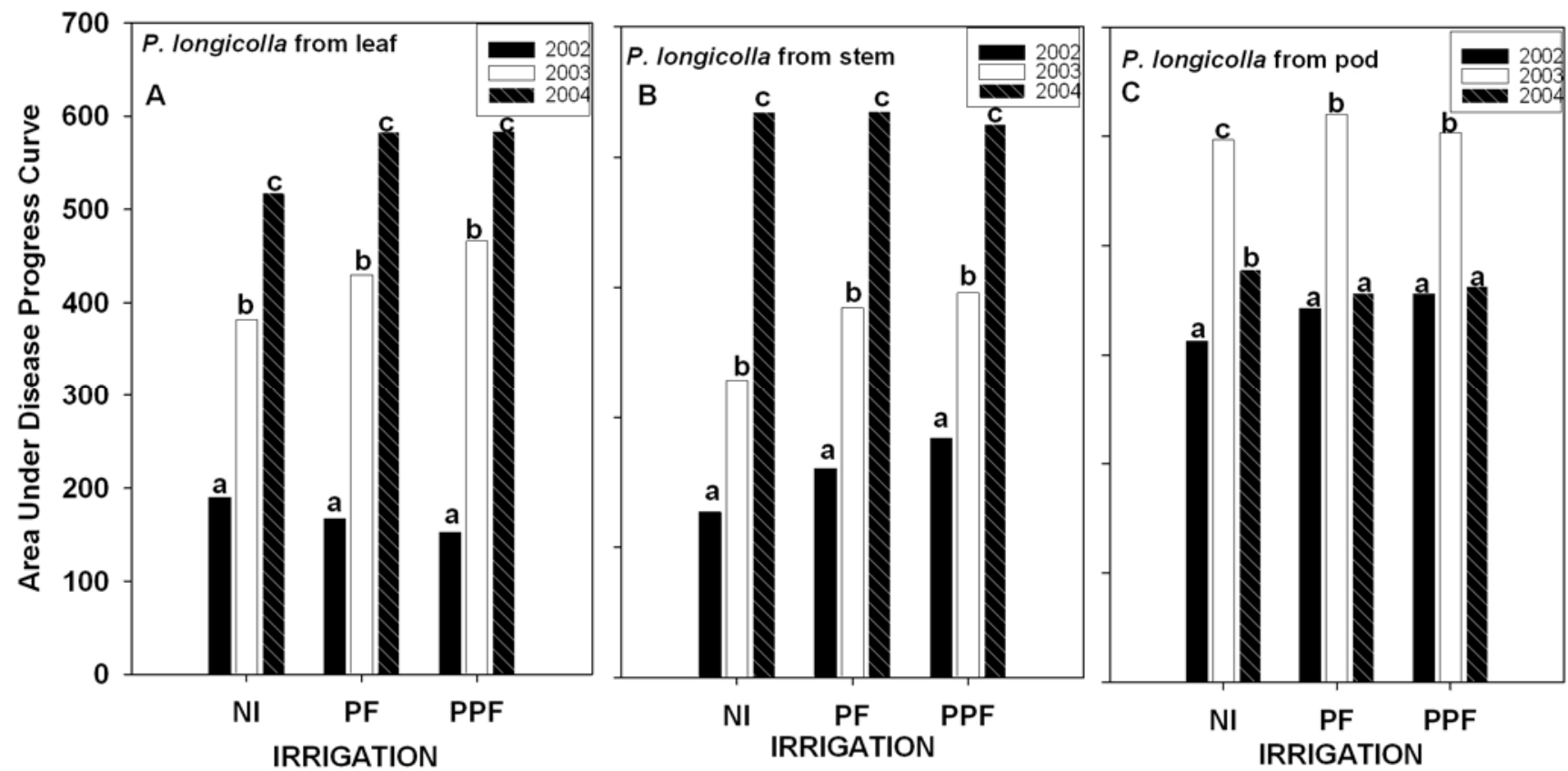

Fig. 2. Area under the disease progress curve for isolation of Phomopsis longicolla from leaves, stems, and pods across soybean cultivars within nonirrigated (NI), postflower irrigation (PF), and pre- plus postflower (PPF) irrigation in 2002, 2003, and 2004. Means followed by the same letter within each irrigation environment are not significantly different at $P \leq 0.05$.

Table 6. Analysis of variance on the percentage of seed infection by Phomopsis longicolla, seed germination, and hard seed on soybean grown in 2002 to 2004 in Stoneville, MS

\begin{tabular}{|c|c|c|c|c|c|c|c|c|}
\hline \multirow[b]{2}{*}{ Irrigation $^{\mathbf{a}}$} & \multirow[b]{2}{*}{ Effect $^{b}$} & \multirow[b]{2}{*}{ df } & \multicolumn{2}{|c|}{ P. longicolla from seed } & \multicolumn{2}{|c|}{ Seed germination } & \multicolumn{2}{|c|}{ Hard seed } \\
\hline & & & $F$ value & $P>F$ & $F$ value & $P>F$ & $F$ value & $P>F$ \\
\hline \multirow[t]{7}{*}{ NI } & $\mathrm{Yr}$ & 2 & 39.2 & $<0.0001$ & 16.76 & 0.0009 & 28.92 & 0.0001 \\
\hline & Cult & 3 & 19.7 & $<0.0001$ & 2.24 & 0.1059 & 8.2 & 0.0005 \\
\hline & Yr*Cult & 6 & 8.19 & $<0.0001$ & 9.94 & $<0.0001$ & 9.97 & $<0.0001$ \\
\hline & Fung & 1 & 0.27 & 0.6035 & 0 & 0.9926 & 0.17 & 0.6866 \\
\hline & Yr*Fung & 2 & 0.23 & 0.7931 & 0.42 & 0.6601 & 0.28 & 0.7597 \\
\hline & Cult*Fung & 3 & 3 & 0.0361 & 1.36 & 0.2689 & 1.37 & 0.2659 \\
\hline & Yr*Fung*Cult & 6 & 1.3 & 0.2696 & 0.79 & 0.5805 & 1.21 & 0.3218 \\
\hline \multirow[t]{7}{*}{$\mathrm{PF}$} & $\mathrm{Yr}$ & & 8.76 & 0.0008 & 0.76 & 0.4953 & 63.31 & $<0.0001$ \\
\hline & Cult & & 10.22 & $<0.0001$ & 23.54 & $<0.0001$ & 46.06 & $<0.0001$ \\
\hline & Yr*Cult & & 13.74 & $<0.0001$ & 89.64 & $<0.0001$ & 61.23 & $<0.0001$ \\
\hline & Fung & & 0.22 & 0.6417 & 7.87 & 0.0081 & 1.17 & 0.2874 \\
\hline & Yr*Fung & & 1.82 & 0.1762 & 3.54 & 0.0394 & 0.72 & 0.4946 \\
\hline & Cult*Fung & & 0.57 & 0.6399 & 2.34 & 0.0897 & 0.84 & 0.4802 \\
\hline & Yr*Fung*Cult & & 0.9 & 0.5079 & 3.20 & 0.0127 & 1.21 & 0.3257 \\
\hline \multirow[t]{7}{*}{ PPF } & Yr & & 10.67 & $<0.0001$ & 0.95 & 0.3957 & 41.71 & $<0.0001$ \\
\hline & Cult & & 11.29 & $<0.0001$ & 7.1 & 0.0007 & 40.96 & $<0.0001$ \\
\hline & Yr*Cult & & 10.27 & $<0.0001$ & 43.77 & $<0.0001$ & 48.88 & $<0.0001$ \\
\hline & Fung & & 0.47 & 0.497 & 4.19 & 0.0479 & 1.17 & 0.2874 \\
\hline & Yr*Fung & & 0.47 & 0.6277 & 0.13 & 0.8745 & 0.84 & 0.4404 \\
\hline & Cult*Fung & & 0.35 & 0.7865 & 0.69 & 0.5655 & 0.94 & 0.4323 \\
\hline & Yr*Fung*Cult & & 0.99 & 0.4358 & 1.03 & 0.423 & 1.05 & 0.4112 \\
\hline
\end{tabular}

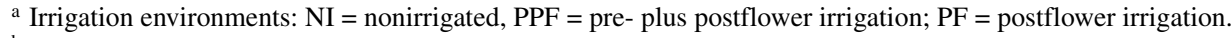

b Abbreviations of fixed effects: $\mathrm{Yr}=$ year, Cult $=$ cultivar, Fung $=$ fungicide.
} 
vars. In contrast, in 2004, germination and percent isolation of $P$. longicolla was lowest for Freedom. In 2004, germination of seed from DK 3964 (MG III) and Freedom (MG V) was lower than that from Dwight (MG II) and DP 4748 (MG IV) under all irrigation environments (Table 7).

Except for Dwight, the percentage of hard seed under nonirrigated environment was higher for all cultivars in 2004 than in 2002 or 2003. Freedom, however, had the highest percentage of hard seed in 2004, ranging from $88 \%$ in nonirrigated and preplus postflower to $100 \%$ under postflower irrigations. In 2004, the hard seed of Dwight ranged from 3 to $9 \%$, and of DP 4748 ranged from 1 to $39 \%$ under all irrigation environments (Table 7). In 2004, under the nonirrigated regime, DK 3964, DP 4748, and Freedom had 85, 39, and $88 \%$ hard seed, respectively. Only Freedom had such high percentages of hard seed under postflower (100\%) and preplus postflower irrigation $(88 \%)$ compared to the other three cultivars. Similar to the AUC for the plant parts, there was no increase or decrease in percent seed infection, seed germination, and hard seed from the one to two additional irrigations ap- plied to Freedom and Pioneer 9594 in the postflower irrigation.

$P$. longicolla was recovered more frequently on seed from irrigated treatments than on seed from the nonirrigated treatment in 2002, 2003, and 2004 (Fig. 3A). The percentage of $P$. longicolla in 2003 was significantly greater within each irrigation than in 2002 or 2004. When comparing seed germination across cultivars within each irrigation environment (Fig. 3B), seed germination in 2004 was lower than in 2002 and 2003. Such a reduction in germination also corresponded to a sharp increase in percentage of hard seed (Fig. 3C).

Table 7. Percentage of seed infected with Phomopsis longicolla and percentage seed germination and hard seed in 2002 , 2003, and 2004 on four soybean cultivars of maturity groups II, III, IV, and V gown under no-irrigation, postflowering, and pre- plus postflower irrigation environments ${ }^{\mathrm{a}}$

\begin{tabular}{|c|c|c|c|c|c|c|c|c|c|c|}
\hline \multirow[b]{2}{*}{ Year } & \multirow[b]{2}{*}{ Cultivar $^{b}$} & \multicolumn{3}{|c|}{ NI } & \multicolumn{3}{|c|}{ PF } & \multicolumn{3}{|c|}{ PPF } \\
\hline & & $\begin{array}{c}\% \text { P. longicolla } \\
\text { isolation from } \\
\text { seed }\end{array}$ & $\begin{array}{l}\text { \% Seed } \\
\text { germi- } \\
\text { nation }\end{array}$ & $\begin{array}{c}\% \\
\text { Hard } \\
\text { seed }\end{array}$ & $\begin{array}{c}\% \text { P. longicolla } \\
\text { isolation from } \\
\text { seed }\end{array}$ & $\begin{array}{l}\text { \% Seed } \\
\text { germi- } \\
\text { nation }\end{array}$ & $\begin{array}{c}\% \\
\text { Hard } \\
\text { seed }\end{array}$ & $\begin{array}{c}\% P \text {. longicolla } \\
\text { isolation from } \\
\text { seed }\end{array}$ & $\begin{array}{l}\text { \% Seed } \\
\text { germi- } \\
\text { nation }\end{array}$ & $\begin{array}{c}\% \\
\text { Hard } \\
\text { seed }\end{array}$ \\
\hline \multirow[t]{5}{*}{2002} & Jack & 18 & 42 & 3 & 11 & 58 & 1 & 16 & 71 & 1 \\
\hline & Dwight & 5 & 62 & 20 & 9 & 82 & 10 & 15 & 89 & 7 \\
\hline & Pioneer 9594 & 5 & 97 & 0 & 36 & 40 & 0 & 32 & 36 & 0 \\
\hline & Freedom & 2 & 89 & 0 & 39 & 27 & 0 & 34 & 35 & 0 \\
\hline & $\operatorname{LSD}(P \leq 0.05)$ & 6 & 8 & 2 & 17 & 16 & 3 & 15 & 17 & 3 \\
\hline \multirow[t]{5}{*}{2003} & Dwight & 20 & 52 & 13 & 33 & 51 & 11 & 34 & 53 & 7 \\
\hline & DK 3964 & 10 & 75 & 0 & 43 & 25 & 0 & 46 & 32 & 0 \\
\hline & DP 4748 & 34 & 43 & 6 & 58 & 27 & 1 & 55 & 26 & 1 \\
\hline & Freedom & 15 & 87 & 0 & 7 & 97 & 0 & 6 & 100 & 0 \\
\hline & $\operatorname{LSD}(P \leq 0.05)$ & 7 & 9 & 4 & 10 & 7 & 2 & 11 & 6 & 2 \\
\hline \multirow[t]{5}{*}{2004} & Dwight & 17 & 62 & 9 & 28 & 85 & 3 & 28 & 76 & 3 \\
\hline & DK 3964 & 2 & 14 & 88 & 37 & 42 & 0 & 31 & 43 & 0 \\
\hline & DP 4748 & 5 & 59 & 39 & 19 & 58 & 13 & 19 & 81 & 1 \\
\hline & Freedom & 1 & 14 & 88 & 2 & 2 & 100 & 1 & 14 & 88 \\
\hline & $\operatorname{LSD}(P \leq 0.05)$ & 4 & 36 & 36 & 6 & 8 & 14 & 7 & 14 & 14 \\
\hline
\end{tabular}

a Irrigation environments: NI = no-irrigation, $\mathrm{PF}=$ postflowering, and PPF = pre- plus postflower irrigation environments. LSD can be used to compare cultivars within each year and irrigation environment. Values represent significance at $P \leq 0.05$.

b Jack (MG II), Dwight (MG II), Pioneer 9594 (MG V), and Freedom (MG V) were grown in 2002; Dwight (MG II), DK 3964 (MG III), DP 4748 (MG IV), and Freedom (MG V) were grown in 2003 and 2004. Pioneer and Freedom were still at the late vegetative stage when the postflower irrigation was applied.
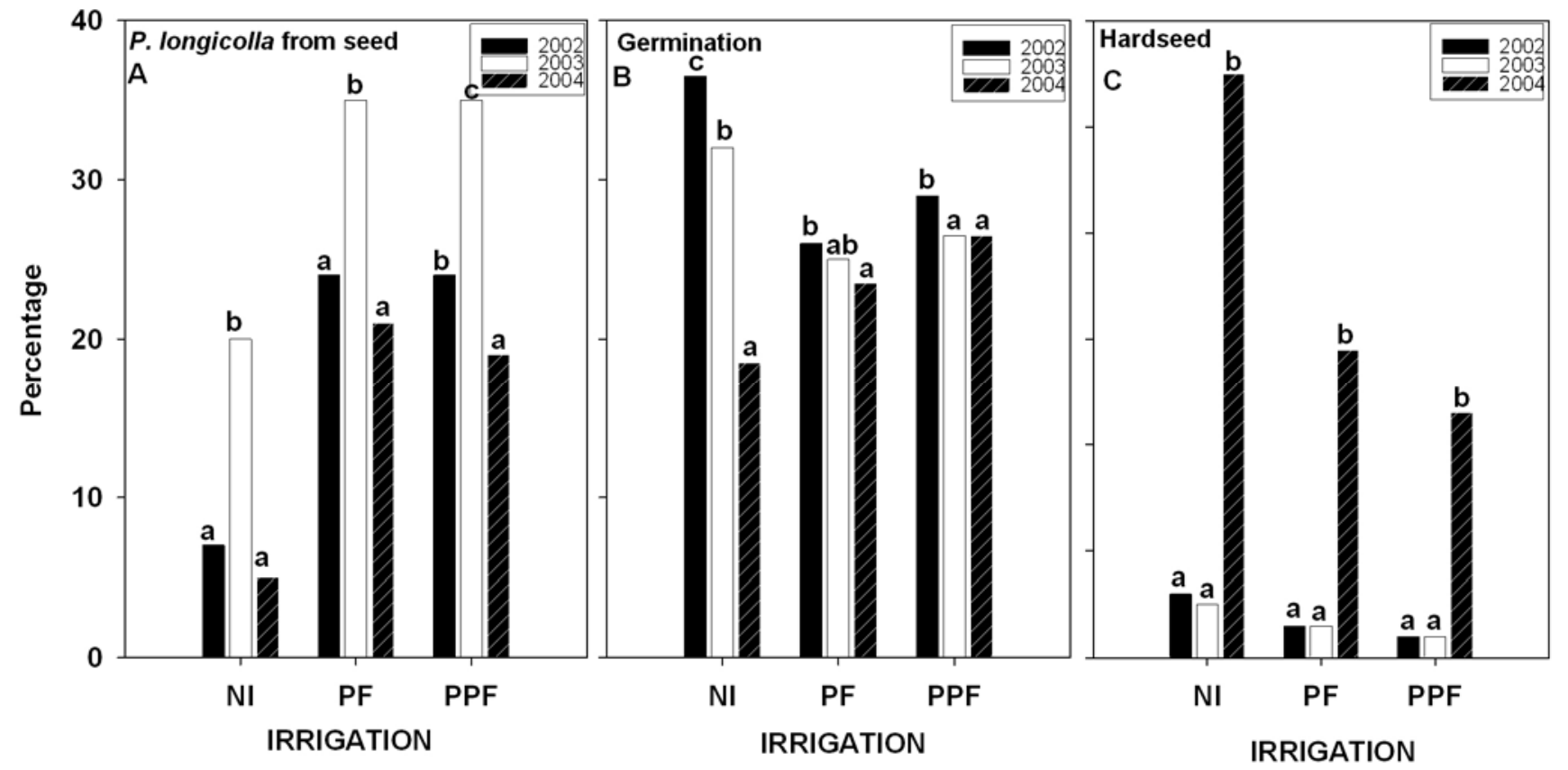

Fig. 3. Percent recovery of Phomopsis longicolla, seed germination, and seed hardness across cultivars within nonirrigated (NI), postflower irrigation (PF), and pre- plus postflower (PPF) irrigations in 2002, 2003, and 2004. Means followed by the same letter within each irrigation environment are not significantly different at $P \leq 0.05$. 
Hard seed for 2002 and 2003 was lower than in 2004. Even though there is no valid statistical comparison to be made between irrigation environments, there was a decrease in percentage of hard seed as irrigation environment changed from nonirrigation to pre- plus postflower irrigations. The nonirrigated regime had higher percentages of hard seed than irrigated regimes, particularly in 2004 (Fig. 3C). The hard seeds in this test germinated later, but required soaking in water for $24 \mathrm{~h}$.

Correlations. Even though there were significant correlations between the various measurements within each irrigation environment, few of the correlation coefficient values were large and few were quite low. There was a low but significant negative correlation between $P$. longicolla recovered from seed and seed germination in postflower $(r=-0.31, P<0.0001, n=96)$ and pre- plus postflower $(r=-0.37, P=$ $0.0024, n=96$ ), but not in the nonirrigated environment (Table 8). Seed germination was strongly and negatively correlated with percent hard seed under no irrigation ( $r=-0.75, P<0.0001, n=96)$ and moderately correlated for postflower $(r=-0.42$, $P<0.0001, n=96)$ and pre- plus postflower irrigation environments $(r=-0.46$, $P<0.0001, n=96)$. There was a low but significant positive correlation between recovery of $P$. longicolla from pods and recovery of $P$. longicolla from seeds in nonirrigation $(r=0.20, P=0.0574, n=$ 96), postflower irrigation $(r=0.23, P=$ $0.0220, n=96$ ), and pre- plus postflower irrigation environments $(r=0.25, P=$ $0.0151, n=96$ ) (Table 8). There were no correlations of $P$. longicolla from leaves and stems with that from seeds. There was also no consistent correlation between yield and infection of plant parts. However, there was a moderate negative correlation between hard seed and yield $(r=$
-0.48, $P<0.0001, n=96)$, hard seed and seed weight $(r=-0.41, P<0.0001, n=$ 96) in nonirrigation, but lower negative correlation between hard seed and yield $(r$ $=-0.24, P=0.0173, n=96)$ between hard seed and seed weight $(r=-0.36, P=0003$, $n=96$ ) for postflower irrigation, and between hard seed and yield $(r=-0.23, P=$ $0.0262, n=96)$ and hard seed and seed weight ( $r=-0.35, P=0.0005, n=96)$ for pre- plus postflower irrigation environments (Table 8). Pod infection was also slightly correlated with seed weight from the postflower $(r=0.24, P=0.0181, n=$ 96) and pre- plus postflower irrigation environments $(r=0.22, P=0.0309, n=$ 96). There was also no correlation between fungicide treatment and all parameters measured, and no data are presented.

\section{DISCUSSION}

$P$. longicolla was recovered from all vegetative plant parts, pods, and seeds within each irrigation environment in the 3 years of this study. Diaporthe phaseolorum, three unknown Phomopsis spp., and Diaporthe aspalathi were recovered at very low frequencies, whereas $P$. longicolla was the major fungal species with the highest isolation frequency. The significance and role of the three new Phomopsis spp. and D. aspalathi on soybean is not known. However, these may be new strains of Phomopsis/Diaporthe that may require further investigation on their pathogenicity on soybeans (Table 3). Two representative live cultures of each taxon are deposited at CBS (Centraalbureau voor Schimmelcultures, Utrecht, the Netherlands), and dried specimens of those that fruited in culture are deposited in BPI, which is the U.S. National Fungus Collections, Beltsville, MD.

In 2002, Pioneer 9594 and Freedom (MG V) had higher AUC values from leaf and stem isolation than Jack and Dwight (MG II) for each irrigation environment (Table 5), indicating that these cultivars had accumulated more infection during the season. However, such differences in infection level between the cultivars did not occur in 2003 and 2004, probably due to the high combined effects of precipitation and irrigation in these two years (Fig. 1). Comparison of the AUC between postflower and pre- plus postflower irrigations for leaf, stem, and pod isolations for Pioneer 9594 and Freedom (Table 5) did not show a consistent pattern of increase or decrease due to the additional irrigation water. There is no satisfactory way to compare cultivars of different maturities and growth habits across uniform environments. Maturity and environment will always be confounded in these types of studies and need to be viewed in that context.

The recovery of $P$. longicolla from leaves, stems, and pods was generally lower in 2002 than in 2003 and 2004. This may have been due to higher temperature and lower precipitation in 2002 than in 2004 during the critical months of June through August (Table 2). It may also be due to lower initial inoculum in the ground compared to that of 2003 and 2004.

Fungicide sprays with Benlate did not affect $P$. longicolla infection on any plant part and seed except on the stem under postflower irrigation (Table 4). It may mean that two applications rather than one may be necessary for Benlate fungicide to have a positive effect on incidence of infection by $P$. longicolla, seed germination, and hard seed.

The AUC from stems of all the cultivars was consistently higher than the AUC from leaves and pods except only in 2003, where AUC for pod was higher. This increase in AUC for stem may be due to a

Table 8. Pearson's correlation coefficients between percent isolation of Phomopsis longicolla from soybean leaves, stems, pods, and percent seed infection, percent seed germination, percent hard seed, yield and seed weight for soybean cultivars gown under no-irrigation (NI), postflowering (PF), and pre- plus postflower (PPF) irrigation environments over 3 years at Stoneville, $\mathrm{MS}^{\mathrm{a}}$

\begin{tabular}{|c|c|c|c|c|c|c|}
\hline Irrigation & $\begin{array}{l}\text { Infections } \\
\text { and seed germination }\end{array}$ & Seed germination & Seed infection & Hard seed & Yield & Seed weight \\
\hline NI & Leaf infection & -0.13 & -0.09 & $0.28 *$ & $-0.25 * *$ & $-0.36 * *$ \\
\hline $\mathrm{PF}$ & & $-0.21^{*}$ & 0.15 & $0.23 *$ & -0.14 & -0.09 \\
\hline PPF & & $-0.25 *$ & 0.13 & $0.22 *$ & -0.16 & -0.12 \\
\hline $\mathrm{NI}$ & Stem infection & $-0.28 *$ & -0.16 & $0.42 * *$ & $-0.37 * *$ & $-0.44 * *$ \\
\hline $\mathrm{PF}$ & & $-0.25^{* *}$ & 0.19 & $0.28 * *$ & -0.11 & -0.19 \\
\hline PPF & & $-0.30 * *$ & 0.07 & 0.17 & -0.14 & -0.15 \\
\hline $\mathrm{NI}$ & Pod infection & 0.08 & $0.20 *$ & -0.08 & 0.06 & -0.02 \\
\hline $\mathrm{PF}$ & & -0.04 & $0.23 *$ & -0.07 & 0.01 & $0.24 * *$ \\
\hline PPF & & -0.04 & $0.25 * *$ & -0.08 & -0.01 & $0.22 *$ \\
\hline $\mathrm{NI}$ & Seed germination & & -0.07 & $-0.75 * *$ & $0.53 * *$ & 0.13 \\
\hline $\mathrm{PF}$ & & & $-0.31 * *$ & $-0.42 * *$ & -0.11 & 0.09 \\
\hline PPF & & & $-0.37 * *$ & $-0.46 * *$ & -0.11 & 0.08 \\
\hline NI & Seed infection & & & $-0.33 * *$ & 0.13 & $0.37 * *$ \\
\hline $\mathrm{PF}$ & & & & $-0.39 * *$ & $0.29 * *$ & $0.36 * *$ \\
\hline PPF & & & & $-0.37 * *$ & 0.14 & $0.38 * *$ \\
\hline $\mathrm{NI}$ & Hard seed & & & & $-0.48 * *$ & $-0.41 * *$ \\
\hline $\mathrm{PF}$ & & & & & $-0.24^{*}$ & $-0.36^{* *}$ \\
\hline PPF & & & & & $-0.23^{*}$ & $-0.35 * *$ \\
\hline
\end{tabular}

a * Indicates significance at $P \leq 0.05, * *$ indicates highly significance at $P \leq 0.05$. 
high relative humidity and temperature under the complete canopy coverage that may have provided a favorable microclimate for higher infection of stems than either leaf or pod infection. The significant correlations between pod and seed infections in all 3 years support earlier reports that measuring pod infection could be a predictor for incidence of seed infection by $P$. longicolla (20). The AUC showed an increased infection from 2002 to 2004, and this may be due to the repeated addition of infected debris each year in the experimental plots. Plant samples taken prior to spray inoculation had $P$. longicolla, indicating that inoculum from debris may have caused such infection.

The result from the 3 years' study demonstrated that recovery of $P$. longicolla from seeds was strongly affected by irrigation environment. Seed harvested from irrigated plots had more $P$. longicolla than that from nonirrigated plots (Fig. 3A). This corroborates an earlier study that indicated that the level of $P$. longicolla in seed increases with irrigation (22). However, in 2003, Freedom, a late-maturing cultivar (MG V), had a lower percentage of seed infection and a higher percentage of seed germination under all irrigation environments. This may be due to the shifting of seed maturation to cooler, drier conditions (30-33). In contrast, Freedom had more $P$. longicolla on seed than earlier maturing cultivars when irrigated in 2002. Germination sharply dropped for both Pioneer 9594 and Freedom in both irrigated environments, with a corresponding increase in the isolation of $P$. longicolla from these two cultivars. This may suggest that moisture from rain can also increase the relative humidity in the canopy and provide a favorable environment for seed infection (22). Early planted and early maturing cultivars are harvested in August through early September under conditions that are typically hot and dry. This seed may have reduced levels of infection relative to seed harvested later in the season, depending on temperature and moisture conditions near maturity and harvest (22).

Isolation of $P$. longicolla from seed was negatively correlated with percent seed germination in irrigated environment but not in nonirrigated environment. Such a relationship between seed infection and seed germination has been established in earlier findings $(5,19,32)$. However, this study demonstrates that seed infection and seed germination are better correlated in irrigated environment than in nonirrigated environment. The significant negative correlation between percent hard seed and percent seed infection and percent germination in all irrigations was in agreement with the findings of Roy et al. (27) that impermeable seeds are less likely to be infected with Phomopsis. In addition, the fact that $P$. longicolla isolation from seed was also negatively correlated with hard seed indicates that the infection level decreased with percent increase of hard seed. Differences in percentage of hard seed of cultivars have been attributed to genetic variation (14). However, in this study, it is likely that the environmental conditions in 2004 may have been the major contributor to increased levels of hard seed. It is difficult to determine which environmental factor(s) or combinations of factors were responsible for increased hard seed. Hard seed characteristics may impact soybean seed processing into soy foods, and this may result in adverse quality and cost factor(s) (24).

This study indicates that seed infection by $P$. longicolla was moisture and cultivar dependent. The level of infection of seed for some cultivars increased with an increase in moisture availability during the growing season. This was evidenced in Stoneville, MS in 2001 when nearly 10 inches of rain fell from 11 August to 3 September and an extreme seed rot problem occurred due to severe infection by $P$. longicolla (22). The occurrence of uninterrupted rain made it impossible for harvesting equipment to enter the field for several days, resulting in severe infection of seed by $P$. longicolla.

Seed weight was positively correlated with seed infection, indicating that as seed size increased the level of seed infection also increased. The current study represents the first attempt to monitor the seasonal progress of $P$. longicolla on soybean cultivars grown under three irrigation environments with early-planted soybeans.

\section{ACKNOWLEDGMENTS}

We thank Debbie Boykin, USDA statistician, for her assistance with data analysis. We also thank the Mississippi Soybean Promotion Board for providing funding to support this study. In addition, we thank Larry Heatherly, a retired agronomist of the USDA, Stoneville, MS for his support in conducting the field planning and irrigation, and Avis Clark and Sandra Mosley for their assistance in laboratory and field tests.

\section{LITERATURE CITED}

1. Baird, R. E., Abney, T. S., and Mullinix, B. G. 2001. Fungi associated with pods and seeds during the R6 and R8 stages of four soybean cultivars in southwestern Indiana. Phytoprotection 82:1-11.

2. Balducchi, A. J., and McGee, D. C. 1987. Environmental factors influencing infection of soybean seeds by Phomopsis and Diaporthe species during seed maturation. Plant Dis. 71:209-212.

3. Barnett, H. L., and Hunter, B. B. 1998. Illustrated Genera of Imperfect Fungi, 4th ed. American Phytopathological Society, St. Paul, MN.

4. Bradley, C. A., Hartman, G. L., Wax, L. M., and Pedersen, W. L. 2002. Quality of harvested seed associated with soybean cultivars and herbicides under weed-free conditions. Plant Dis. 86:1036-1042.

5. Brown, E. A., Minor, H. C., and Calvert, O. H. 1987. A soybean genotype resistant to soybean seed decay. Crop Sci. 27:895-898.

6. Fehr, W. R., and Caviness, C. R. 1977. Stages of soybean development. Iowa State University Coop. Ext. Serv. Spec. Rep. 80.
7. Hartman, G. L., Sinclair, J. B., and Rupe, J. C. 1999. Compendium of Soybean Diseases. 4th ed. American Phytopathological Society, St. Paul, MN.

8. Heatherly, L. G. 1996. Yield and germinability of seed from irrigated and non-irrigated early and late planted MG IV soybean. Crop Sci. 36:1000-1006.

9. Heatherly, L. G. 1999. Early soybean production system (ESPS). Pages 103-118 in: Soybean Production in the Midsouth. L. G. Heatherly and H. F. Hodges, eds. CRC Press, Boca Raton, FL.

10. Heatherly, L. G., and Elmore, C. D. 1983. Response of soybeans to planting in untilled, weedy seedbed on clay soil. Agron. J. 78:575580.

11. Hepperly, P. R., and Sinclair, J. B. 1978. Quality losses in Phomopsis-infected soybean seeds. Phytopathology 68:1684-1687.

12. Hobbs, T. W., Schmitthenner, A. F., and Kuter, G. A. 1985. A new Phomopsis species from soybean. Mycologia 77:534-544.

13. Jordan, E. G., Manandhar, J. B., Thapliyal, P. N., and Sinclair, J. B. 1986. Factors affecting soybean seed quality in Illinois. Plant Dis. 70:246-248.

14. Kilen, T. C., and Hartwig, E. E. 1978. An inheritance study of impermeable seed in soybeans. Field Crops Res. 1:65-70.

15. Kmetz, K. T., Ellett, C. W., and Schmitthenner, A. F. 1979. Soybean seed decay: Sources of inoculum and nature of infection. Phytopathology 69:798-801.

16. Kmetz, K. T., Schmitthenner, A. F., and Ellett, C. W. 1978. Soybean seed decay: Prevalence of infection and symptom expression caused by Phomopsis sp., Diaporthe phaseolorum var. sojae, and D. phaseolorum var. caulivora. Phytopathology 68:836-840.

17. Kulik, M. M., and Sinclair, J. B. 1999. Phompsis seed decay. Pages 31-32 in: Compendium of Soybean Diseases, 4th ed. G. L. Hartman, J. B. Sinclair, and J. C. Rupe, eds. American Phytopathological Society, St. Paul, MN.

18. MAFES and MCES. 1998. Weed control guidelines for Mississippi Agricultural and Forestry Experiment station and Mississippi Cooperative Extension Service, Mississippi State University, Mississippi State, 167.

19. Mayhew, W. L., and Caviness, C. E. 1994 Seed quality and yield of early-planted, short season soybean genotypes. Agron. J. 86:16-19.

20. McGee, D. C., and Nyvall, R. F. 1986. Prediction of PSD by measuring soybean pod infection. Plant Dis. 70:329-333.

21. Mengistu, A., Castlebury, L. A., Smith, J. R., Rossman, A. Y., and Reddy, K. N. 2007. Identification and pathogenicity of Phomopsis isolates from weed hosts and their effect on soybean. Can. J. Plant Pathol. 29:283-289.

22. Mengistu, A., and Heatherly, L. G. 2006. Planting date, irrigation, maturity group, year, and environment effects on Phomopsis longicolla, seed germination, and seed health rating of soybean in the early soybean production system of the midsouthern USA. Crop Prot. 25:310-317.

23. Miller, W. A., and Roy, K. W. 1982. Effect of benomyl on colonization of soybean leaves, pods, and seeds by fungi. Plant Dis. 66:918920 .

24. Mullin, J. W., and Xu, W. 2001. Study of soybean seed coat components and their relationship to water absorption. J. Agric. Food Chem. 49:5331-5335.

25. Rensburg, J. V., Lamprecht, S. C., Groenewald, J. Z., Castlebury, L. A., and Crous, P. W. 2006. Characterization of Phomopsis spp. associated with die-back of rooibos (Aspalathus linearis) in South Africa. Stud Mycol. 55:65-74.

26. Ross, J. P. 1975. Effect of overhead irrigation and benomyl sprays on late season diseases, seed infection, and yields of soybean. Plant 
Dis. Rep. 59:809-813.

27. Roy, K. W., Keith, B. C., and Andrews, C. H. 1994. Resistance of hardseeded soybean lines to seed infection by Phomopsis, other fungi, and soybean mosaic virus. Can. J. Plant Pathol. 16:122-128.

28. SAS Procedures Guide, Version 8, 1999. SAS Institute, Cary, NC.

29. Schilder, A. M. C., Erincik, O., Castlebury, L., Rossman, A., and Ellis, M. A. 2005. Characterization of Phomopsis spp. infecting grapevines in the Great Lakes region of North America. Plant Dis. 89:755-762.

30. Shortt, B. J., Grybauskas, A. P., Tenne, F. D., and Sinclair, J. B. 1981. Epidemiology of Phomopsis seed decay of soybean in Illinois. Plant Dis. 65:62-64.
31. TeKrony, D. M., Egli, D. B., and Balles, J. 1980. The effect of the field production environment on soybean seed quality. Pages 403425 in: Seed Production. P. D. Hebblethwaite, ed. Butterworth, London.

32. TeKrony, D. M., Egli, D. B., Balles, J., Tomes, L., and Stuckey, R. E. 1984. Effect of date of harvest maturity on soybean seed quality and Phomopsis sp. seed infection. Crop Sci. 24:189-193.

33. TeKrony, D. M., Egli, D. B., Stuckey, R. E., and Balles, J. 1983. Relationship between weather and soybean seed infection by Phomopsis sp. Phytopathology 73:914-918.

34. TeKrony, D. M., Grabau, L. J., DeLacy, M., and Kane, M. 1996. Early planting of early-maturing soybean: Effects on seed germination and Pho- mopsis infection. Agronomy 88:428-433.

35. Tooley, P. W., and Grau, C. R. 1984. Field characterization of rate reducing resistance to Phytophtora megasperma f. sp. glycines in soybean. Phytopathology 74:1201-1208.

36. Vanderplank, J. E. 1963. Plant Diseases: Epidemics and Control. Academic Press, New York

37. Wrather, J. A., Kendig, S. R., Wiebold, W. J., and Riggs, R. D. 1996. Cultivar and planting date effects on soybean stand, yield, and Phomopsis sp. seed infection. Plant Dis. 80:622624.

38. Zorrilla, G., Knapp, A. D., and McGee, D. C. 1994. Severity of Phomopsis seed decay, seed quality evaluation, and field performance of soybean. Crop Sci. 34:172-177. 